\title{
Can orthodontic need cause bullying?
}

\section{A necessidade de ortodontia pode causar bullying?}

\author{
Ana Kátia Altoé VIEIRA1 ID https://orcid.org/0000-0003-4180-223X \\ Diego Patrik Alves CARNEIRO2 (iD https://orcid.org/0000-0001-7864-3055 \\ Marcelo de Castro MENEGHIM² iD https://orcid.org/0000-0003-2673-3627 \\ Silvia A. S. VEDOVELLO1 ID https://orcid.org/0000-0002-7203-2867 \\ Heloísa Cristina VALDRIGHI ${ }^{1}$ iD https://orcid.org/0000-0001-7567-1990
}

\begin{abstract}
Objective: To determine the association between orthodontic treatment need and the self-reported bullying, and its impact on adolescents' self-esteem. Methods: The sample consisted of 160 schoolchildren from 11 to 14 years of age, enrolled in public schools. The history of bullying was evaluated by means of the Crozier; Dimmock adapted Questionnaire (1999). Self-esteem was determined by means of the Global Negative Self-Evaluation Scale (GSE). The normative orthodontic treatment need was determined by the Dental Health Component (DHC) and perceived need, by Aesthetic Component (AC) of the Index of Orthodontic Treatment Need (IOTN). Individual analyses were made of the associations with the history of bullying (outcome). Results: The variables that presented $P \leq 0.20$ in the individual analyses were tested in a multiple logistic regression model, and variables with $P \leq 0.05$ remained in the model. The odds ratios with the intervals of confidence were estimated. According to the results $72.5 \%$ of the schoolchildren reported a history of bullying. The schoolchildren who presented negative impact on the quality of life related to oral symptoms and negative self-esteem were observed to have 4.59 and 5.44 times more chance, respectively to report a history of bullying $(P<0.05)$, which did not suffer the influence of normative and perceived orthodontic treatment need. Conclusion: The history of bullying was not influenced by orthodontic treatment need, but by the low self-esteem of adolescents.
\end{abstract}

Indexing terms: Bullying. Orthodontic treatment need. Self-Esteem.

\section{RESUMO}

Objetivo: Determinar a associação entre a necessidade de tratamento ortodôntico e o bullying autorrelatado e seu impacto na autoestima dos adolescentes. Métodos: A amostra foi composta por 160 escolares de 11 a 14 anos, matriculados em escolas públicas. A história de bullying foi avaliada por meio do Questionário Crozier; adaptado por Dimmock (1999). A autoestima foi determinada por meio do Global Negative Self-Evaluation Scale (GSE). A necessidade normativa de tratamento ortodôntico foi determinada pelo Componente de Saúde Bucal (DHC) e a necessidade percebida, pelo Componente Estético (AC) do Índice de Necessidade de Tratamento Ortodôntico (IOTN). Foram realizadas análises individuais das associações com a história de bullying (desfecho). Resultados: As variáveis que apresentaram $P \leq 0.20$ nas análises individuais foram testadas em modelo de regressão logística múltipla, permanecendo

\footnotetext{
$\boldsymbol{\nabla} \mathbf{v} \boldsymbol{V}$

1 Fundação Hermínio Ometto, Faculdade de Odontologia de Araras, Departamento de Ortodontia. Av. Dr. Maximiliano Baruto, 500, 13607-339, Araras, SP, Brasil. Correspondence to: HC VALDRIGHI. E-mail: <heloisavaldrighi@gmail.com>.

2 Universidade Estadual de Campinas, Faculdade de Odontologia de Piracicaba, Departamento de Odontologia Comunitária. Piracicaba, SP, Brasil.

$\because \boldsymbol{v} \mathbf{u}$

How to cite this article

Vieira AKA, Carneiro DPA, Meneghim MC, Vedovello SAS, Valdrighi HC. Can orthodontic need cause bullying?. RGO, Rev Gaúch Odontol. 2021;69:e20210047. http://dx.doi.org/10.1590/1981-863720210004720190090
} 
no modelo as variáveis com $P \leq 0.05$. Foram estimados os odds ratios com os intervalos de confiança. De acordo com os resultados, $72.5 \%$ dos escolares relataram história de bullying. Os escolares que apresentaram impacto negativo na qualidade de vida relacionado aos sintomas bucais e autoestima negativa tiveram 4.59 e 5.44 vezes mais chance, respectivamente, de relatarem história de bullying $(P<0.05)$, e não sofreram influência da necessidade de tratamento ortodôntico normativa e percebida. Conclusão: A história de bullying não foi influenciada pela necessidade de tratamento ortodôntico, mas pela baixa autoestima dos adolescentes.

Termos de indexação: Bullying. Necessidade de tratamento ortodôntico. Autoestima.

\section{INTRODUCTION}

Bullying at school-going age is endemic [1] a practice that occurs among students [2], with a prevalence ranging from $5 \%$ to $58 \%[1,3,4]$. Considered a subtype of violence, it is characterized by negative actions, performed by physical contact, words or other forms, such as gestures or intentional exclusion from a group on the part of one or more students in an unequal relationship of power $[3,5]$. Although it is still a very invisible behaviour, it especially affects children and adolescents who suffer the consequences of continuous aggressive processes [6]. School bullying has been extensively studied in high income countries; however, in the low to medium income countries, the individual and contextual characteristics associated with bullying are not well known [7].

The relationship of bullying with dentofacial characteristics, and quality of life have been investigated $[4,8,9]$. Adolescents with malocclusion are known to have negative impact on their self-esteem and quality of life [10-13]. Characteristics such as the appearance of the mouth and smile cause negative impact on the quality of life and have a significant relationship with bullying $[1,14]$. This situation is accentuated as the malocclusion becomes more severe [14], because adolescents who have been intimidated due to the presence of a malocclusion had a global negative result with impact on their quality of life [10]. On the other hand, adolescents who were victims of bullying and underwent orthodontic treatment, had a significant reduction in the level of intimidation, with positive impact on the quality of life [15].

Occlusal problems identified by the professional and appreciated by an objective evaluation, sometimes do not represent a compromised aesthetic appearance of the adolescent $[16,17]$. In some cases, negative self-esteem is associated with the presence of bullying, without being directly related to the orthodontic treatment need [4]. The relationship between normative malocclusion, bullying, self-esteem and their ability to influence quality of life is complex [15] and has been little discussed. There is no evidence about the relationship between perceived orthodontic treatment need and self-reported bullying. In this context, the aim of this study was to evaluate the association between orthodontic treatment need and the self-reported bullying, and its impact on adolescents' self-esteem.

\section{METHODS}

\section{Subjects and methods}

The study design was in accordance with the Declaration of Helsinki for Human Rights and was reviewed and approved by the Committee for Ethics in Research on Humans at the University (process $n^{\circ} 1.598 .454 / 2016$ ). The guardians of the participants signed a statement of informed consent, and the adolescents agreed to participate in the study. Based on $80 \%$ power, significance level of $5 \%$, and considering $50 \%$ correlation coefficient between the variables, this cross-sectional study was conduct with 160 adolescents aged 11 to 14 years. Excluded from the study were adolescents who had previously been submitted to orthodontic treatment, those with physical or intellectual deficiencies that would impede the exam being performed, and/or those whose parents did not authorize their participation in the study. The evaluation included data on ethnicity of the adolescent.

\section{Dependent variable}

The instrument used to verify perception of the history of bullying was adapted from the questionnaire of Crozier \& Dimmock [18]. Eight questions were self-applied, the first (1 ${ }^{\text {st }}$ ) related to the nicknames reported by the adolescents, the second ( 2 nd) about the harmful provocation, the third $\left(3^{\text {rd }}\right)$ about unpleasant comments, the fourth $\left(4^{\text {th }}\right)$ related to false stories, the fifth (5th) to coarse nicknames, the sixth (6th) to threats/ provocations, the $\left(7^{\text {th }}\right)$ related to discrimination, and the eighth (8th) about being offended. Each response 
received a binomial classification. The responses were added and the adolescents were classified according to the median, between this with and those without bullying (chart 1).

Chart 1. Questions used to assess the history of bullying.

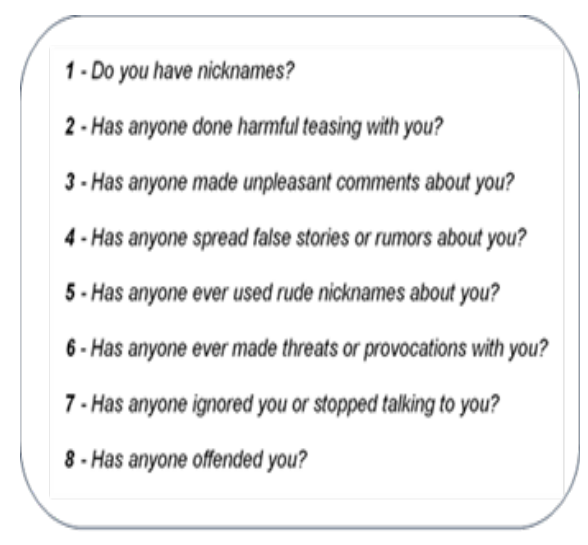

\section{Independent variable}

Self-esteem related to the adolescents' malocclusion was evaluated by the Global Negative Self-Evaluation Scale (GSE) $[11,19]$ by means of six questions. Each question contained six response options marked from 1 to 6: 1 , does not apply at all; 2, does not apply well; 3, applies somewhat well; 4, applies fairly well; 5, applies well; and 6, applies exactly. The scores were added to obtain the average self-esteem score of each schoolchild, with the following interpretations: 1-1.69 (very little negative evaluation), 1.7-2.69 (a little negative), 2.7-3.99 (negative evaluation) and 4-6 (very negative).

The normative orthodontic treatment need was determined by the Dental Health Component (DHC) of the Orthodontic Treatment Need Index - IOTN $[11,20]$. The IOTN-DHC classifies malocclusions (exaggerated overjet, negative overjet, exaggerated overbite, anterior or posterior open bite, crowding, anterior or posterior crossbite and missing teeth) according to the severity of the occlusal characteristics in five degrees; IOTN-DHC 1 and 2 represent without/little need, IOTN-DHC 3 a moderate need, and IOTN-DHC 4 and 5 a definitive treatment need. The adolescents were classified as having little treatment need (1 and 2) and high treatment need (3, 4 and 5), for the purpose of data analysis.
The IOTN-AC evaluates individuals' psychosocial needs by means of a dental attractiveness scale illustrated by 10 colour photographs that present a decreasing and continuous degree of attractiveness, in which Photo 1 represents the most attractive dental arrangement, and Photo 10 the least attractive. The adolescents themselves made the evaluations, identifying the degree of aesthetic compromise in the photographs of the scale, by considering it similar to their own smile. Photos 1 to 4 are related to individuals with no or little orthodontic treatment need (IOTN-AC 1 and 2); Photos 5, 6 and 7 with moderate orthodontic treatment need (IOTN-AC 3) e as Photos 8, 9 and 10 are related to severe orthodontic treatment need (IOTN-AC 4 and 5) [11,20]. The IOTN-AC was dichotomized into little treatment need (1 and 2) and high treatment need $(3,4$ and 5$)$.

\section{Statistical analysis}

Initially, individual analyses were made of the associations among independent variables (age, sex, race, normative and perceived orthodontic treatment need, and self-esteem) with the history of bullying (outcome). The variables that presented $p \leq 0.20$ in the individual analyses were tested in a multiple logistic regression model, and variables with $p \leq 0.05$ remained in the model. The raw and adjusted odds ratios (OR) with their respective intervals of confidence were estimated. All the analyses were performed in the software program (SAS Institute Inc., Cary, NC, USA, release 9.2, 2010); considering the level of significance of $5 \%$.

\section{RESULTS}

Of the 160 school children analysed, 116 (72.5\%) reported a history of bullying. The majority of the sample were in the age range from $11-12$ years of age $(63.1 \%)$, of whom $53.8 \%$ were of the male sex. $52.5 \%$ of the adolescents presented high orthodontic treatment need, according to the normative diagnostic criteria (IOTN-DHC). Relative to the perceived need (IOTN-AC), 89.4\% presented without/little orthodontic treatment need.

Of the independent variables analysed, only self-esteem presented statistical significance $(P<0.05)$, with negative/very negative self-esteem being found in $39.4 \%$ of the adolescents. Schoolchildren with negative 
self-esteem presented 6.12 (2.40-15.58) times more chance of reporting a history of bullying, which showed no significant association with orthodontic treatment need (figure 1 and table 1).

\section{DISCUSSION}

The relations between bullying, malocclusion and influence on self-esteem of adolescents is complex, seeing that the results of this study pointed out a high prevalence of self-report bullying among the adolescents. Adolescence was the age group chosen in this study because, according to the literature [21], the relation between student-level bullying victimization and emotional engagement was different across middle and high schools. Therefore, orthodontic treatment need should be better understood, and so must its relationship with self-esteem and bullying.

In this study, $72.5 \%$ of the adolescents reported bullying, in agreement with the results of previous studies $[3,14,22,23]$. However, the history of bullying presented no association with orthodontic treatment need, corroborating

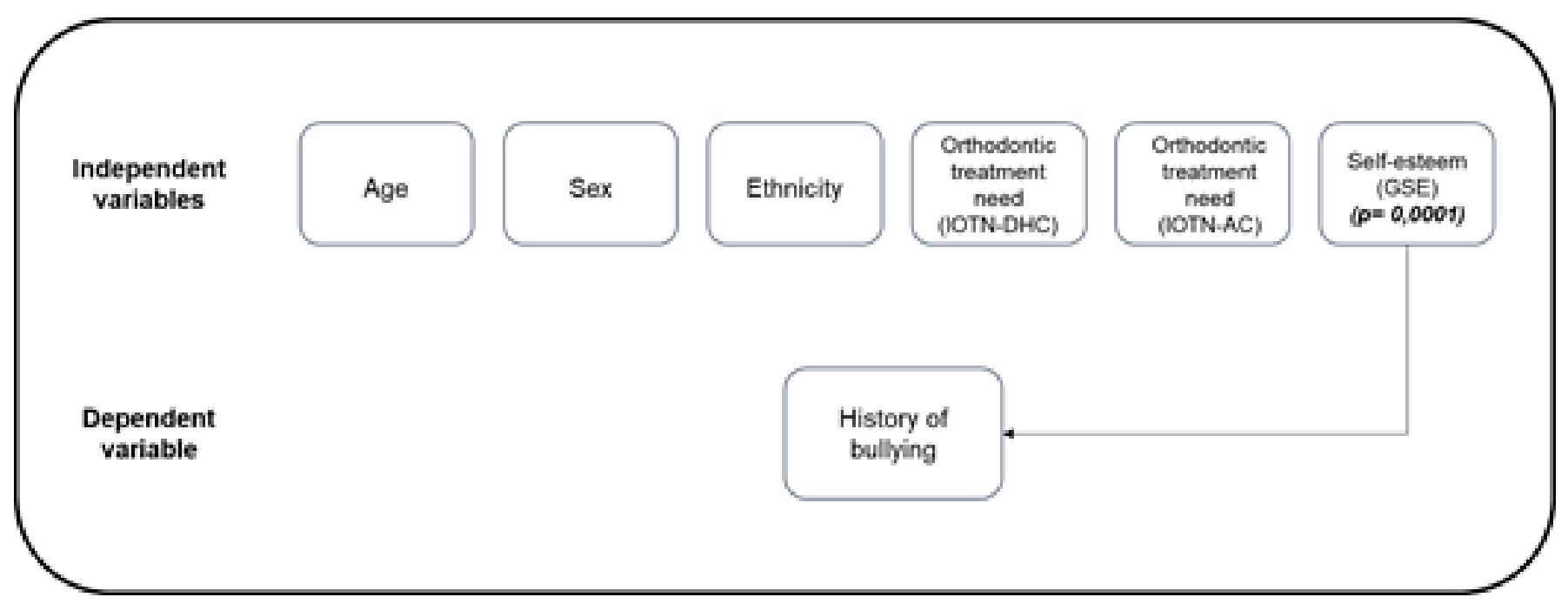

Figure 1. Flowchart of the results.

Table 1. Individual analysis of relationship between history of bullying due to independent variables.

\begin{tabular}{|c|c|c|c|c|c|c|}
\hline \multirow{2}{*}{ Variables } & & \multirow{2}{*}{$\mathrm{n}(\%)$} & \multicolumn{2}{|c|}{ History of bullying } & \multirow{2}{*}{${ }^{\circledR} \mathrm{OR}(\mathrm{IC} 95 \%)$} & \multirow{2}{*}{$P$} \\
\hline & & & Não & Sim & & \\
\hline \multirow{2}{*}{ Age } & $11-12$ & $101(63.1)$ & $29(28.7)$ & $72(71.3)$ & 1 & \\
\hline & $13-14$ & 59 (36.9) & $15(25.4)$ & $44(74.6)$ & $1.18(0.57-2.44)$ & 0.6532 \\
\hline \multirow{2}{*}{ Sex } & Female & $74(46.2)$ & $19(25.7)$ & $55(74.3)$ & $1.19(0.59-2.39)$ & 0.6318 \\
\hline & Male & $86(53.8)$ & $25(29.1)$ & $61(70.9)$ & 1 & \\
\hline \multirow{3}{*}{ Ethnicity } & Brown & $61(38.1)$ & $15(24.6)$ & $46(75.4)$ & 1 & \\
\hline & White & $41(25.6)$ & $18(43.9)$ & $23(56.1)$ & $0.42(0.18-0.97)$ & 0.0432 \\
\hline & Black & $58(36.2)$ & $11(19.0)$ & $47(81.0)$ & $1.39(0.58-3.35)$ & 0.4590 \\
\hline \multirow{2}{*}{$\begin{array}{l}\text { Orthodontic treatment need } \\
\text { (IOTN-DHC) }\end{array}$} & No/minor & $76(47.5)$ & $18(23.7)$ & $58(76.3)$ & 1 & \\
\hline & Defined/Severe & $84(52.5)$ & $26(31.0)$ & $58(69.0)$ & $0.69(0.34-1.39)$ & 0.3050 \\
\hline \multirow{2}{*}{$\begin{array}{l}\text { Orthodontic treatment need } \\
\text { (IOTN-AC) }\end{array}$} & No/minor & $143(89.4)$ & $39(27.3)$ & $104(72.7)$ & 1 & \\
\hline & Defined/Severe & $17(10.6)$ & $5(29.4)$ & $12(70.6)$ & $0.90(0.30-2.70)$ & 0.8519 \\
\hline \multirow{2}{*}{ Self-esteem (GSE) } & High & $97(60.6)$ & $38(39.2)$ & $59(60.8)$ & 1 & \\
\hline & Low & $63(39.4)$ & $6(9.5)$ & $57(90.5)$ & $6.12(2.40-15.58)$ & 0.0001 \\
\hline
\end{tabular}

\& Gross Odds Ratio (95\% confidence interval). 
with Gatto et al. [4]. The results of our study were probably due to the fact that the majority of the adolescents had no perception of the existence of occlusal problems and had no desire to undergo orthodontic treatment, so that this was not a causal factor of bullying. On the other hand, studies have shown that individuals may be intimidated by the presence of malocclusion [14] and present a significant relationship of bullying with dentofacial characteristics $[1,4]$. In addition, these studies $[14,15]$ had a convenience sample (patients with the presence of malocclusion and desire to undergo orthodontic treatment), who affirmed that orthodontic treatment had a positive impact on the individuals' quality of life, with a reduction in the level of bullying.

Of the studied adolescents, $52.5 \%$ presented malocclusion (IOTN-DHC), however, without negative impact on self-esteem. Moreover, $10.6 \%$ of the adolescents perceived the need treatment need (IOTN-AC). The probable hypothesis that justified these findings was that as the occlusal problems did not affect the adolescents' self-esteem, they did not perceive the malocclusion, and consequently, they did not feel demotivated by this condition. Although some individuals identified the malocclusion, they did not perceive the treatment need in the same way as the orthodontist did, and thus, the normative orthodontic treatment need overestimated the need perceived by the adolescents. Similar results have also been observed by other authors [17,24,25].

On the other hand, self-esteem showed association with the history of bullying. Adolescents with negative self-esteem presented 6.12 more chance of reporting a history of bullying. However, it was not possible to affirm whether the presence of bullying was the cause of low self-esteem or vice-versa. Although bullying is still a very invisible behaviour, children and adolescents suffer the consequences of these continuous aggressive processes [6]. Behaviours of depression and psychosocial complaints have been associated with bullying by other authors $[14,26,27]$.

Bullying at school-going age causes intimidation, harming the well-being of individuals [1,2], who present greater tendency towards depression in comparison with those who are in involved in the behaviour of bullying [26]. Adolescents who are intimidated due to the presence of malocclusion have a negative impact on their quality of life, with emotional changes $[28,29]$. Although the majority of the adolescents in the present study did not perceive the orthodontic problems, and this condition was not the cause of bullying, malocclusion is of significant relevance.
The present study had limitations because it was a cross-sectional study, without observing the cause and effect relationship. The high prevalence of bullying suggests that qualitative and/or case control studies should be conducted, because this phenomenon could be underestimated in other populations and have causes that are not yet known. To complement and go more deeply into the findings of this research, the authors suggest the use of a longitudinal approach to understand the desires and feelings of adolescents who are victims of bullying, and the consequences of these episodes on their adult lives.

\section{CONCLUSION}

The history of bullying was not influenced by orthodontic treatment need, but by the low self-esteem of adolescents.

\section{Collaborators}

AKA VIEIRA participated in the data collection and writing the manuscript.; DPA CARNEIRO, MC MENEGHIM and SAS VEDOVELLO participated in the study design, contributed to the data analysis and reviewing the manuscript; HC VALDRIGHI supervised all stages of research from conception and design of the project, writing and final revision of the text. All authors reviewed the text and approved its final version.

\section{REFERENCES}

1. Al-Omari IK, Al-Bitar ZB, Sonbol HN, Al-Ahmad HT, Cunningham SJ, Al-Omiri M. Impact of bullying due to dentofacial features on oral health quality of life. Am J Orthod Dentofacial Orthop. 2014;146(6): 734-9. http://dx.doi. org/10.1016/j.ajodo.2014.08.011

2. Mello FCM, Silva JLD, Oliveira WA, Prado RRD, Malta DC, Silva MAI. The practice of bullying among Brazilian schoolchildren and associated factors, National School Health Survey 2015. Cien Saude Colet. 2017 Sep;22(9):2939-2948. http://dx.doi. org/10.1590/1413-81232017229.12762017

3. Garbin CAS, Gatto RCJ, Garbin AJl. Prevalência de bullying em uma amostra representativa de adolescentes brasileiros. Arch Health Invest. 2016;5(5):256-61. http://dx.doi.org/10.21270/ archi.v5i5.1701

4. Gatto RCJ, Garbin AJl, Corrente JE, Garbin CAS. Selfesteem level of Brazilian teenager's victms of bullying and its relation with the need of orthodontic treatment. RGO, Rev Gaúch Odontol. 2017 Jan-Mar; 65(1): 30-6. http://dx.doi. org/10.1590/1981-863720170001000053304

5. Bhui K, Silva MJ, Harding S, Stansfeld S. Bullying, Social support, and psychological distress: findings from RELACHS 
Cohorts of East London's white British and Bangladeshi adolescents. J Adolesc Health. 2017 Sep;61(3):317-328. http://dx.doi.org/10.1016/j.jadohealth.2017.03.009

6. Låftman SB, Alm S, Sandahl J, Modin B. Future orientation among students exposed to school bullying and cyberbullying victimization. Int J Environ Res Public Health. 2018 Apr;15(4): 605. http://dx.doi.org/10.3390/ijerph15040605

7. Azeredo CM, Levy RB, Araya R, Menezes PR. Individual and contextual factors associated with verbal bullying among Brazilian adolescents. BMC Pediatr. 2015 May;15:49. http:// dx.doi.org/10.1186/s12887-015-0367-y

8. Chester KL, Spencer NH, Whiting L, Brooks FM. Association between experiencing relational bullying and adolescent health-related quality of life. J Sch Health. 2017 Nov;87(11):865-872. http://dx.doi.org/10.1111/josh.12558

9. Hidalgo-Rasmussen CA, Ramírez-López G, Rajmil L, Skalicky A, Martín AH. Bullying and health-related quality of life in children and adolescent Mexican students. Cien Saude Colet. 2018 Jul;23(7):2433-2441. http://dx.doi.org/10.1590/141381232018237.16392016

10. Kragt L, Dhamo B, Wolvius EB, Ongkosuwito EM. The impact of malocclusions on oral health-related quality of life in children-a systematic review and meta-analysis. Clin Oral Investig. 2016 Nov;20(8):1881-1894. http://dx.doi. org/10.1007/s00784-015-1681-3

11. Dos Santos PR, Meneghim MC, Ambrosano GM, Filho MV, Vedovello SA. Influence of quality of life, self-perception, and self-esteem on orthodontic treatment need. Am J Orthod Dentofacial Orthop. 2017 Jan;151(1):143-147. http://dx.doi. org/10.1016/j.ajodo.2016.06.028

12. Sun L, Wong HM, McGrath CPJ. Association between the severity of malocclusion, assessed by occlusal indices, and oral health related quality of life: a systematic review and meta-analysis. Oral Health Prev Dent. 2018;16(3):211-223. http://dx.doi.org/10.3290/j.ohpd.a40761

13. Singh TK, Bhagia P, Gupta U, Passi D, Goyal J, Yadav G, et al. Effect of orthodontic treatment needs on oral health related quality of life among the young population in Delhi NCR-region of North India. J Family Med Prim Care. 2019 Feb;8(2):550-555. http://dx.doi.org/10.4103/jfmpc.jfmpc_431_18

14. Gatto RCJ, Garbin AJÍ, Corrente JE, Garbin CAS. The relationship between oral health-related quality of life, the need for orthodontic treatment and bullying, among Brazilian teenagers. Dental Press J Orthod. 2019 May;24(2):73-80. http://dx.doi.org/10.1590/2177-6709.24.2.073-080.oar

15. Seehra J, Newton T, DiBiase AT. Interceptive orthodontic treatment in bullied adolescents and its impact in selfesteem and oral-health-related quality of life. Eur J Orthod 2013;35:615-21. http://dx.doi.org/10.1093/ejo/cjs051

16. Scapini A, Feldens CA, Ardenghi TM, Kramer PF. Malocclusion impacts adolescent's oral health-related quality of life. Angle Orthod. 2013;83(3):512-8. http://dx.doi.org/10.2319/062012509.1

17. Santos NR, Cabo I, Almeida F, Castro S, Ponces MJ, Lopes JD. Aplicação do índice de necessidade de tratamento ortodôntico numa população ortodôntica portuguesa. Rev Port Estomatol Cir Maxilofac. 2014;55(3):159-66. http:// dx.doi.org/10.1016/j.rpemd.2014.06.002
18. Crozier WR, Dimmock PS. Name-calling and nicknames in a sample of primary school children. Br J Educ Psychol. 1999 Dec; 69: 505-16

19. Alsaker FD, Olweus D. Assessment of global negative selfevaluations and perceived stability of self in Norwegian preadolescents and adolescents. J Early Adolesc. 1986;6:269-78

20. Brook PH, Shaw WC. The development of an index of orthodontic priority. Eur J Orthod 1989; 11: 309-20. http:// dx.doi.org/10.1093/oxfordjournals.ejo.a035999

21. Yang C, Sharkey JD, Reed LA, Chen C, Dowdy E. Bullying victimization and student engagement in elementary, middle, and high schools: Moderating role of school climate. Sch Psychol Q. 2018 Mar;33(1):54-64. http://dx.doi.org/10.1037/ spq0000250

22. Modecki KL, Minchin J, Harbaugh AG, Guerra NG, Runions KC. Bullying prevalence across contexts: a metaanalysis measuring cyber and traditional bullying. J Adolesc Health. 2014 Nov;55(5):602-11. http://dx.doi.org/10.1016/j. jadohealth.2014.06.007

23. Han Z, Zhang G, Zhang H. School Bullying in Urban China: Prevalence and Correlation with School Climate. Int J Environ Res Public Health. 2017 Sep;14(10). pii: E1116. http://dx.doi. org/ 10.3390/ijerph14101116

24. Almeida AB, Leite IC, Melgaço CA, Marques LS. Dissatisfaction with dentofacial appearance and the normative need for orthodontic treatment: determinant factors. Dental Press J Orthod 2014; May-June, 19(3):120-6. http://dx.doi org/10.1590/2176-9451.19.3.120-126.oar

25. Ghijselings I, Brosens V, Willems G, Fieuws S, Clijmans M, Lamiere J. Normative and self-perceived orthodontic treatment need in 11- to16-year-old children. Eur J Orthod 2014; 36(2): 179-85. http://dx.doi.org/10.1093/ejo/cjt042

26. Espelage DL, Holt MK. Suicidal ideation and school bullying experiences after controlling for depression and delinquency. J Adolesc Health. 2013 Jul;53(1Suppl): S27-31. http://dx.doi. org/10.1016/j.jadohealth.2012.09.017

27. Hong L, Guo L, Wu H, Li P, Xu Y, Gao X, et al. Bullying, Depression, and Suicidal Ideation Among Adolescents in the Fujian Province of China: A Cross-sectional Study. Medicine (Baltimore). 2016 Feb; 95(5):e2530. http://dx.doi. org/10.1097/MD.0000000000002530

28. Dimberg L, Arnrup K, Bondemark L. The impact of malocclusion on the quality of life among children and adolescents: a systematic review of quantitative studies. Eur J Orthod. 2015 Jun;37(3):238-47. http://dx.doi.org/10.1093/ ejo/cju046

29. da Rosa GN, Del Fabro JP, Tomazoni F, Tuchtenhagen S, Alves LS, Ardenghi TM. Association of malocclusion, happiness, and oral health-related quality of life (OHRQoL) in schoolchildren. J Public Health Dent. 2016 Mar;76(2):85-90. http://dx.doi. org/10.1111/jphd.12111

Received on: 3/6/2019 Final version resubmitted on: 1/10/2019 Approved on: 25/6/2020 